\title{
CORRESPONDENCE ANALYSIS AS A TOOL FOR COMPUTER MODELING OF SUSTAINABLE DEVELOPMENT
}

\section{Kateryna Berezka}

Ternopil National Economic University, Ternopil, Ukraine

e-mail: km.berezka@gmail.com

ORCID 0000-0002-9632-4004

\section{Olha Kovalchuk}

Ternopil National Economic University, Ternopil, Ukraine e-mail: Olhakov@gmail.com

ORCID 0000-0001-6490-9633

(C) 2018 Kateryna Berezka, Olha Kovalchuk

This is an open access article distributed under the Creative Commons Attribution-NonCommercial-NoDerivs license (http://creativecommons.org/licenses/by-nc-nd/3.0/)

DOI: 10.15611/eada.2018.4.01

JEL Classification: E01, E27, C15

\begin{abstract}
Many of the problems that the world faces today appeared as the result of unstable development. Global climate change, resource depletion, space debris, poverty, inequality, and threats to global security are the main but not the only challenges for modern humanity. The important issue in studying the problems of sustainable development of the countries in the world is the development of strategies that would give an opportunity to avoid environmental and social catastrophes. The correspondence analysis is used to identify the relationship between the Happy Planet Index (which is an aggregate indicator of achievements in the key aspects of human development, such as life duration and quality, distribution uniformity, access to knowledge, and preservation of environment) and Gross National Income (one of the basic metrics of the population welfare level). The analysis led to the conclusion that the income level of the population is not the main factor in assessing the level of sustainable development of a country. The obtained results can give important and useful information for social institutions and politicians.
\end{abstract}

Keywords: sustainability development, correspondence analysis, computer modeling, Happy Planet Index, Gross National Income. 
Kateryna Berezka, Olha Kovalchuk

Modern society lives in a world guided and managed by data

\section{Introduction}

One of the primary global problems of humanity in the 21 st century is the issue of ensuring the sustainable development of society. Sustainability is a goal of a modern knowledge-based society. Sustainable development is a general model of society, which implies a balance between meeting the current needs of people and protecting the interests of future generations, in particular, a safe and healthy environment [Butlin 1987]. This is a manageable development based on a systematic approach and modern information technologies that allow the quick and efficient modeling of various development options with a high predicted probability of results and effective decision-making.

In the modern sense, human development means a wide range of rights, freedoms and opportunities. The most important of them are healthy longevity, education and an adequate standard of living. The additional choices include political freedom, guaranteed human rights and personal self-respect ("Human Development Report", 1990). The main goal of the human development policy is to expand the opportunities that ensure a decent and meaningful life. Economic growth is only a means for this but not an end in itself. Today, for social development, social factors such as the high level of poverty, insufficient level of education and health service provision, high inequality, and unemployment are extremely critical. To ensure the sustainable development of the world's countries, it is necessary to link the idea of human development to alternative goals, including maximizing public happiness and striving for economic growth [Stewart, Samman 2018].

Today, to guarantee the effective sustainable development of countries, especially developing countries, it is necessary to use various tools of mathematics and statistics and apply the latest achievements of science and technology. The nations and the world as a whole face many developmental problems, which can be solved with the help of mathematical models that describe the economy-society-nature system with the help of mathematical concepts and the language of mathematics.

The main goal of the study is to identify the interdependency between the main measure of sustainable wellbeing, the Happy Planet Index (HPI), and the traditional indicator of a country's income level, Gross National Income (GNI) per capita.

\section{Sustainable development modeling}

In modern society, information and scientific knowledge are the decisive factors of development. The newest information technologies open up radically new opportunities and ways of information processing in social, economic, and political spheres. 
Sustainable development refers to a new area of hope and expectation that unfavorable forecasts will not happen. This can be a fundamental feature of global development processes and a reference point for the mutual consideration and interpretation of nature/society development [Todorov, Marinova 2010].

Since the twentieth century, globalization has become a characteristic feature of development that affects the economy making it global, a society with the emergence of global consciousness and common global problems, and a polluted environment. In fact, sustainability becomes a globalized development that does not contradict but synchronizes and strengthens these processes - the Earth can support such a development.

An adequate model of sustainable development cannot build on the existing understanding of society and nature. People have also created what can be called a "second nature". This is a human material world, which by size and importance can be compared to global natural systems. It does not only act as a buffer between people and nature but also has become the main goal of human development. This "second nature" is threatening the nature of the planet [Todorov, Marinova 2010].

For many decades, scientists from around the world have been studying sustainable development. However, the modern science of sustainability does not clearly explain how to achieve resilience to the environmental and socio-economic changes. The concept of sustainable development embraces a wide range of human activities, including the ecological impact on natural ecosystems, as well as on economic stability and social integrity. The need to take into account all three main areas of sustainable development leads to additional complexity in measuring sustainability.

From a technical perspective, the main problems of adequate evaluation of sustainability are lack of data, the inconsistency of data in different areas, as well as the need for big data analysis. In addition, the understanding of happiness, wellbeing, security, freedom and other socio-economic categories by which researchers "measure" sustainability is subjective. Currently the most successful method of sustainability evaluation is the use of various metrics and indicators.

Today there are a large number of indicators for sustainability quantitative evaluation. However, there is no general integral indicator to measure a country's ability for a happy life while preserving a quality habitat for future generations.

The existing models of sustainable development usually focus mainly on solving global problems and they are ideological and associated with political programs. Such models are specific; they consider a narrow locally global perspective and reflect a particular moment. They are restricted in time, take into account only individual trends and cannot manage uncertainty.

\subsection{Problems of estimating the social indicators in sustainability}

The quantitative analysis of a social component of sustainable development is complex and difficult. For any country or region, this is a matter of scientific 
knowledge consolidated with different types of relationships between the individual and society (gratitude, emotional intelligence, intuitive comprehension, tradition, sense of security, life satisfaction, etc.).

Every person must take part in sustainable development. It is a process of continuous improvement, training, and preparation. Every person living on Earth today should contribute to various aspects of our existence for the security and prosperity of future generations. This is the only solution to ensure the future of humanity.

Due to the scientific aspect of measuring the social component of sustainable development and the imperfect methods of its evaluation efficiency, the quantitative analysis of sustainability is limited. In addition, it is always necessary to take into account the time and place, as social standards do not remain unchanged. The application of computing techniques reveals new opportunities not only for quantitative analysis (measurement) but also for modeling the social components of sustainability. The computer simulation of decision-making process, conflict resolution with the help of the apparatus of a game theory, construction scenarios for the systems based on the models of the theory of disasters, etc. have all gained particular importance.

The fundamental characteristic of social indicators is that the object of cognition is a subject, that is, a conscience bearer. The important feature of the social component is its stochastic character as a result of the fact that various actions of many people should be evaluated using a number of qualitative indicators that are not subject to quantitative description. The social component is characterized by its complexity and the large number of factors that depend on many objective and subjective conditions [Oprean at al. 2009].

The main difficulties in developing the technology for sociological evaluation are related to the measurement of qualitative characteristics. Therefore, measuring the values of sustainability of social components involves solving the problem of measuring the qualitative characteristics and their representation in a quantitative form. The solution to this problem is not limited to the identification of the qualitative indicators within the phenomenon to be studied, but rather needs an assessment of such characteristics.

Thus the main problem of mathematical modeling is the right choice of qualitative indicators and its processing using nonparametric statistical methods (including associations and correspondence analysis), the construction of a more complex system of social statistics, the consideration of the specificity of social phenomena, and the improvement of correlation analysis and factor analysis.

To develop an effective model of sustainable development, it is necessary to have a clear and deep knowledge about the socio-economic and environmental characteristics of the region where there is a social process to be studied. In the absence of such information, all mathematical models and the precise methodology for the study of specific phenomena will be incomplete. 


\section{Empirical application}

One of the standard ratings for the traditionally measured level of sustainable development of countries and regions is the Human Development Index (HDI). The Human Development Index was developed by the United Nations Development Program (UNDP) on the basis of Sen's scientific works [Sen 1999]. It is a general measure of progress in the key aspects of human development: a long, healthy life, being knowledgeable and a decent standard of living. However, the estimation accuracy is confusing due to the imbalance in the three dimensions [Hack 2018].

Despite its global success, HDI has several disadvantages regarding the distribution issues. A single measure cannot correctly reflect the distribution of the level of quality of education, health and life in all the countries of the world with a million people population. Empirical evidence suggests significant differences in these three dimensions, not only in different countries but also within them. Therefore, the United Nations included "reducing inequality within and among countries" as one of the key goals of Sustainable Development Goals (SDGs) for the global development agenda [Permanyer, Smits 2018].

National research studies on the equal distribution of measuring human development are quite rare, and each uses a separate approach. Therefore it is reasonable to study further the problems of choosing an optimal set of indicators for the appropriate assessment of country sustainable development. In the new Human Development Report (HDR), launched by UNDP in 1990, alongside the human development index, the central role is assigned to the measurement of welfare analysis [Hack 2018].

According to empirical studies [Kovalchuk 2017], HDI and GDP per capita are not able to clearly assess the real level of sustainable development of a country, including the well-being and quality of life, competitiveness, inequality, poverty, security, expansion of rights and freedoms, self-realization, access to information, cleanliness of the environment, etc.

\subsection{Analysis of the relationship between the National Happy Planet Index and the Gross National Income Index}

In their studies on the problems of sustainable development, modern scientists often use other dimensions of human prosperity instead of HDI and GDP, in particular wellbeing, Human Capital and the Gross National Income, etc.

We analyzed the relationship between the Happy Planet Index (HPI) [The Happy Planet Index 2016] and the Gross National Income (GNI) per capita ("GNI per capita, Atlas method (current US \$) - Country Ranking”, 2018).

The Happy Planet Index is an indicator of sustainable wellbeing. It compares how effectively residents of different countries use natural resources to achieve a long, happy, guaranteed (in the sense of sustainability) life. HPI is an aggregate measure and its value is approximately calculated by the following equation: 
Happy Planet Index $\approx \frac{(\text { Expectancy wellbeing } \times \text { Life expectancy }) \times \text { Inequality of outcomes }}{\text { Ecological footprint }}$,

where Life expectancy is the average life expectancy of residents in a particular country, Expectancy wellbeing is the importance of well-established living conditions in this country, Inequality of outcomes is a measure of how irregularly distributed life expectancy and wellbeing in a given country, Ecological footprint is a measure of human needs in the ecosystems of the planet.

Rich Western countries usually show the standard of success. However, they do not rank highly on the Happy Plane Index. Some countries in Latin America and the Asia-Pacific region are leading in this rating by their high life expectancy and wellbeing with a much smaller ecological footprint than in the highly developed countries. The population of the vast majority of the developed countries uses more natural capital than is generated on their own territory. Thus, the burden on the environment in developed countries is greater than that of others. Currently, the socalled ecological boundaries have been established which should ensure the recovery of natural resources after the impact of human activity on the existing lifestyle. They include 2.2 hectares per inhabitant of the planet. The UN calculates the ecological footprint of mankind annually [The Happy Planet Index 2016].

Ultimately one cannot buy happiness for money. Therefore many rich countries of the world are not far up on the list of the happiest countries in the world, including the USA (108) and Japan (58). The obvious difference between wealth and happiness has led to the need to find other indicators for assessing the welfare of nations instead of simply assessing economic progress for GDP. However, happiness or well-being is a subjective category that is difficult to quantify.

The research was performed with the analytics platform Statistica 10 based on official sources in 2016 for 190 countries [The Happy Planet Index 2016; GNI per capita 2018].

Table 1. Table of distribution of the countries of the world into groups according to the values of HPI and GNI

\begin{tabular}{|l|l||l|c|}
\hline \multicolumn{2}{|c||}{ Happy Planet Index } & \multicolumn{2}{c|}{ Gross national income per capita, US\$ } \\
\hline \multicolumn{1}{|c|}{ Ranking } & Range & \multicolumn{1}{c|}{ Ranking } & Range \\
\hline Very high & $>36.1$ & high & $>30000$ \\
\hline High & $36.1-32.7$ & middle & $5000-30000$ \\
\hline Upper-middle & $32.6-28.8$ & lower-middle & $1000-5000$ \\
\hline Middle & $28.7-24.8$ & low & $<1000$ \\
\cline { 1 - 2 } Lower-middle & $24.7-21$ & \multicolumn{2}{|c}{} \\
\cline { 1 - 2 } Low & $20,7-16,8$ & & \\
\cline { 1 - 2 } Very low & $<16,8$ & &
\end{tabular}

Source: [https://www.indexmundi.com/facts/indicators/NY.GNP.PCAP.CD/rankings; http://happyplanetindex.org/countries/]. 
The countries of the world were divided according to the indicators chosen for the study into groups as follows (Table 1).

\subsection{Method of research}

Correspondence analysis is a method designed for the visual and numerical study of the structure of large-dimensional contingency tables. The goal of the correspondence analysis is to represent the distances between points in a space of smaller dimension.

Today, correspondence analysis is being intensively applied in various fields, in particular in sociology, economics, marketing, medicine, and management. There are known applications of the method in archeology and in analysis of texts, where it is important to analyze data structures.

The application of correspondence analysis in economics is associated with the study of the structure of complex tables containing indicator variables that indicate the presence or absence of a corresponding attribute. Such tables have a large dimension, and an investigation of their structure is a non-trivial task.

The task of the visualization of complex objects can be solved with the help of correspondence analysis. The image is a multidimensional table. The task is to find a plane on which one can reproduce the original image as accurately as possible.

Mathematical study method. Correspondence analysis uses a specific interpretation of $\chi^{2}$ according to Pearson. The method is designed to study the connectivity tables. The criterion for the quality of reproduction of a multidimensional table in a space of lower dimension is the value of the statistic $\chi^{2}$. Informally, correspondence analysis can be viewed as a factor analysis of categorical data [Kovalchuk 2017] or as a method of dimensional reduction.

The rows or columns of the source table represent points of space between which the distance $\chi^{2}$ is calculated (similar to how the statistics $\chi^{2}$ are calculated to compare the observed and expected frequencies). Next, we search for a space of small dimension (usually two-dimensional), in which the computed distances are minimally distorted, and in this sense reproduce the structure of the original table as closely as possible, preserving the relationships between the features. The initial information for applying the analysis is the frequency table or cross-tabulation (Figure 1).

The four numbers of each row of the table (marginal frequencies) can be considered as the coordinates of a row in 4-dimensional space. Formally, we can calculate distances $\chi^{2}$ between these points (rows of the table). At such marginal frequencies, it is possible to map these points in a space of dimension 3 (the number of degrees of freedom is 3). Obviously, the smaller the distance, the greater the similarity between groups, and vice versa, the greater the distance, the greater the difference. The aim of the analysis is to search for a space of smaller dimension (for example, dimension 2) for representing the points, which saves almost all information about the differences between the lines. 


\begin{tabular}{l|r|r|r|r} 
& GNI low & GN lower-middle & GNl middle & GNl high \\
\hline HPI very high & 0 & 10 & 2 & 1 \\
\hline HPI high & 0 & 13 & 4 & 2 \\
\hline HPI upper middle & 1 & 8 & 4 & 9 \\
\hline HPI middle & 2 & 13 & 6 & 3 \\
\hline HPI lower-middle & 7 & 13 & 4 & 3 \\
\hline HPI low & 5 & 6 & 2 & 2 \\
\hline HPI very low & 6 & 8 & 1 & 2
\end{tabular}

Fig. 1. Frequency table of the Happy Planet Index and Gross National Income

Source: own study.

\section{Results}

The correspondence analysis can be considered as an expansion of the $\chi 2$ statistic for components in order to determine the space of the smallest dimension, which makes it possible to represent deviations from the expected values.

The calculated eigenvalues provide information about the number of measurements sufficient for a qualitative representation of the table information data. The first dimension in this case extracts $60 \%$ of the total inertia. The inclusion of the second dimension increases the "explained" inertia to $95.8 \%$ (Figure 2).

\begin{tabular}{|c|c|c|c|c|c|}
\hline \multirow[b]{2}{*}{$\begin{array}{l}\text { Number } \\
\text { of Dims. }\end{array}$} & \multicolumn{5}{|c|}{$\begin{array}{l}\text { Eigenwalues and Inertia for all Dimensions (corespond } \\
\text { Input Table (Rows } \times \text { Columns): } 7 \times 4 \\
\text { Total Inertia }=24766 \text { Chi?=33,930 df=18 } \mathrm{p}=, 01288\end{array}$} \\
\hline & $\begin{array}{c}\text { Singular } \\
\text { Values }\end{array}$ & $\begin{array}{l}\text { Eigen- } \\
\text { Values }\end{array}$ & $\begin{array}{l}\text { Perc. of } \\
\text { Inertia }\end{array}$ & $\begin{array}{l}\text { Cumulaty } \\
\text { Percent }\end{array}$ & $\begin{array}{c}\text { Chi } \\
\text { Squares }\end{array}$ \\
\hline 1 & 0,385339 & 0,148485 & 59,95433 & 59,9543 & 20,34247 \\
\hline 2 & 0,297937 & 0,088766 & 35,84150 & 95,7958 & 12,16100 \\
\hline 3 & 0,102040 & 0,010412 & 4,20417 & 100,0000 & 1,42647 \\
\hline
\end{tabular}

Fig. 2. Eigenvalues and inertia for all dimensions

Source: own study.

The largest deviations between observed and expected frequencies are observed in groups of countries with upper-middle HPI and high GNI and countries with very low HPI and low GNI. The real number of countries with an upper-middle level of the Happy Planet Index and a high level of Gross National Income is more than 5 (compared to the expected number), and the number of countries that have a very low level of Happy Planet Index and low Gross National Income is more than 3 compared to the hypothesis about independence etc. (Figure 3 ). 


\begin{tabular}{|c|c|c|c|c|}
\hline & \multicolumn{4}{|c|}{$\begin{array}{l}\text { Observed minus Expected Frequencies (corespont } \\
\text { Input Table (Rows } \times \text { Columns): } 7 \times 4 \\
\text { Total Inertia }=, 24766 \text { Chi?=33,930 df=18 } \mathrm{p}=, 01288\end{array}$} \\
\hline & GNN low & $\begin{array}{c}\text { GNI } \\
\text { lower-middle }\end{array}$ & GNV middle & GNI high \\
\hline HPI very high & $-1,99270$ & 3,26277 & $-0,18248$ & $-1,08759$ \\
\hline HPI high & $-2,91241$ & 3,15328 & 0,81022 & $-1,05109$ \\
\hline HPI upper middle & $-2,37226$ & $-3,40146$ & 0,30657 & 5,46715 \\
\hline HPI middle & $-1,67883$ & 0,56204 & 1,97080 & $-0,85401$ \\
\hline HPI lower-middle & 2,86131 & $-0,99270$ & $-0,53285$ & $-1,33577$ \\
\hline HPI low & 2,70073 & $-1,77372$ & $-0,51825$ & $-0,40876$ \\
\hline HPI very low & 3,39416 & $-0,81022$ & $-1,85401$ & $-0,72993$ \\
\hline
\end{tabular}

Fig. 3. Table of deviations of expected frequencies from supervised ones

Source: own study.

Criterion $\chi^{2}$ Pearson is an objective assessment of the proximity of empirical and theoretical distributions. Achieved level of significance is 0.01 and the results are statistically significant. The number of degrees of freedom $d f=18, \chi^{2}=33.9$ (Figure 4). $\chi^{2}(0.01 ; 18)=34.8$. The calculated criterion value is more than tabular one. Consequently, it can be argued that the predicted values are close enough to the observed ones.

\begin{tabular}{|c|c|c|c|c|c|}
\hline & \multicolumn{5}{|c|}{$\begin{array}{l}\text { Contributions to Chi-Square (Corespondent_HPI_GNI_1) } \\
\text { Input Table (Rows } \times \text { Columns): } 7 \times 4 \\
\text { Total Inertia= } 24766 \text { Chi? }=33,930 \mathrm{df}=18 \mathrm{p}=, 01288\end{array}$} \\
\hline & GNI low & $\begin{array}{c}\text { GNI } \\
\text { lower-middle }\end{array}$ & GNI middle & GNl high & Total \\
\hline HPI very high & 199270 & 1,580130 & 0,015258 & 0,56661 & 4,15470 \\
\hline HPI high & $\overline{2,91241}$ & 1,009799 & 6799 & 0,36210 & 4,49011 \\
\hline HPI upper middle & 1. & 1,014776 & 5446 & 8,46053 & 11,16955 \\
\hline $\mathrm{HPI}$ middle & 0,76613 & 0,025398 & 0,963980 & 0,18924 & 1,94475 \\
\hline HPI lower-middle & 1,97819 & 0,070426 & 0,062637 & 0,41152 & 2,52278 \\
\hline HPI low & 3,17229 & 0,404709 & 0,106654 & 0,06937 & 3,75301 \\
\hline $\mathrm{HPI}$ ye & 2097 & 0,074511 & 1,204398 & 0,19517 & 5,89504 \\
\hline Total & 16,91149 & 4,179748 & 2,584173 & 10,2545 & 33,9299 \\
\hline
\end{tabular}

Fig. 4. Table of cell contribution (cells) in the $\chi^{2}$

Source: own study.

The purpose of the correspondence analysis is to summarize the deviations from the expected frequencies, not in absolute but in relative units.

Analysis of rows and columns. The rows and columns of the data table can be represented by points in a space of smaller dimension, which reproduces the 
similarity (and distances) between the relative frequencies for the columns/ rows of the table as accurately as possible.

\section{Results of graphical correspondence analysis}

Correspondence analysis involves finding a space of lower dimension, which fully represents the data of the table (Figures 5 to 7 ). At the same time, the quality criterion is the normalized $\chi^{2}$, or inertia. The use of one-dimensional space in our studies allowed us to explain $74.39 \%$ of the inertia of the table (Figure 5).

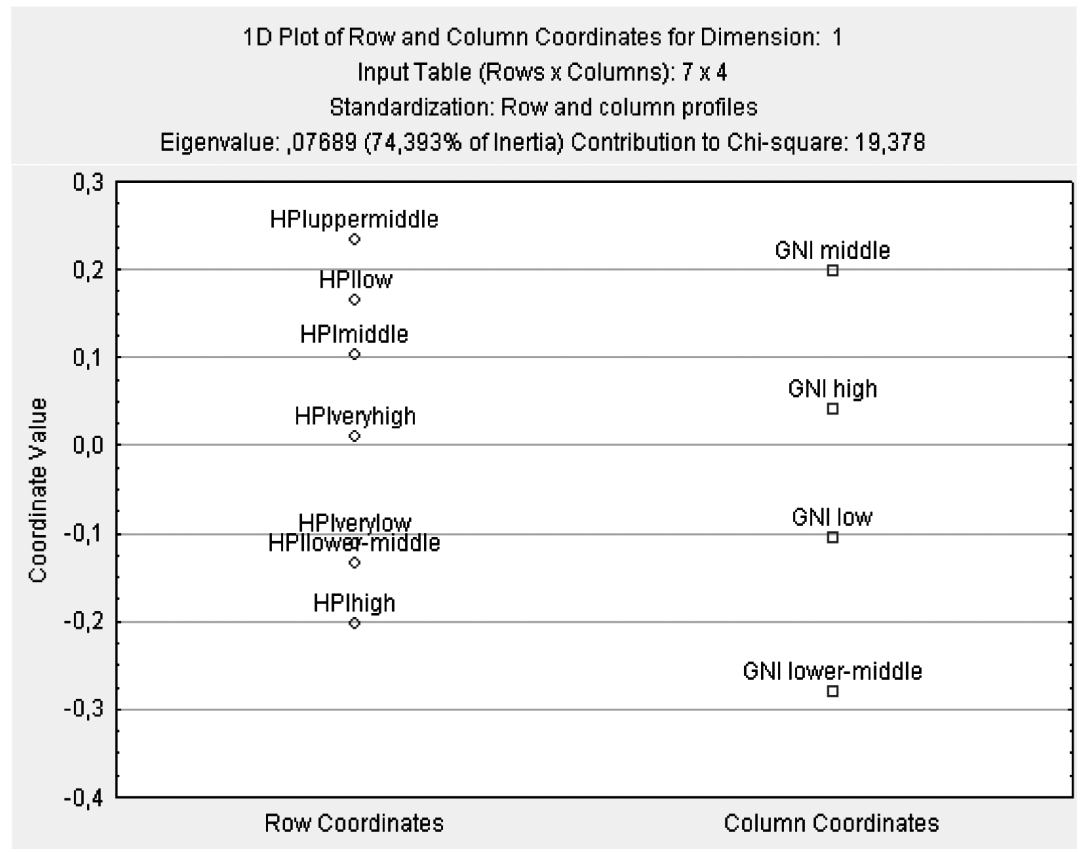

Fig. 5. 1-D graph of coordinates of rows and columns

Source: own study.

Two dimensions make it possible to explain $74.39 \%$ of inertia. An obvious advantage of two-dimensional space is that the lines that are displayed as close points are close to each other and relative frequencies. Considering the position of the points along the first axis, it can be seen that countries with very low HPI and countries with lower-middle HPI are relatively close in coordinates (Figure 6).

The table of relative frequencies (the frequencies are standardized so that their sum on each line is $100 \%$ ) clearly shows the similarity of the data of the two groups in the levels of the Happy Planet Index and Gross National Income (Figures 8 to 9). 


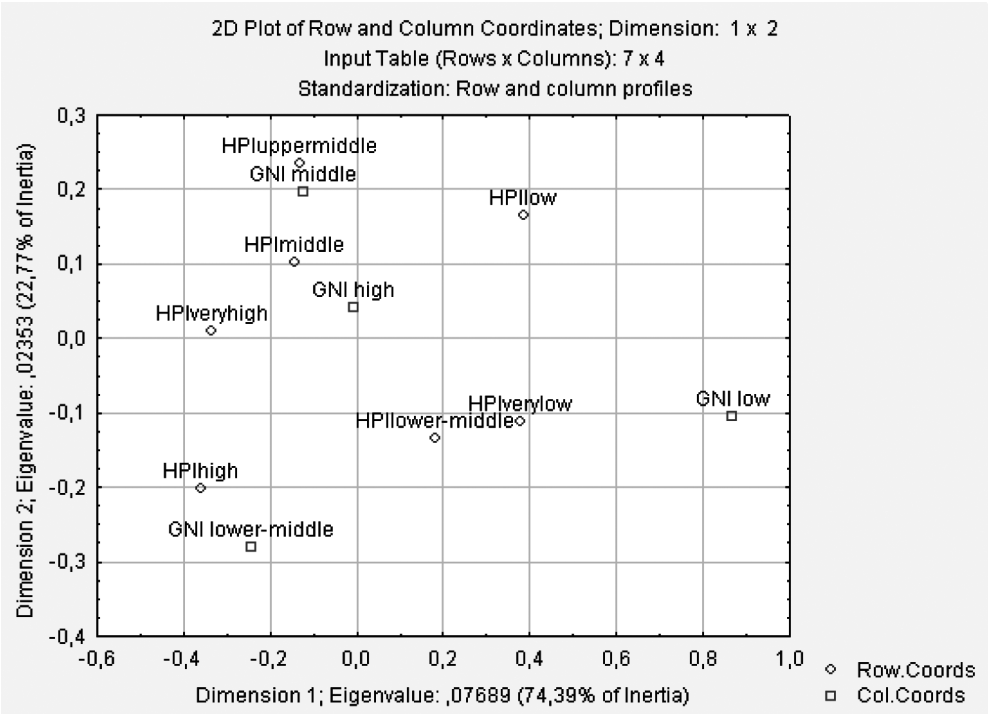

Fig. 6. 2-D coordinate graph of rows and columns

Source: own study.

3D Plot of Row and Column Coordinates; Dimension: $1 \times 2 \times 3$ Input Table (Rows $\times$ Columns): $7 \times 4$

Standardization: Row and column profiles

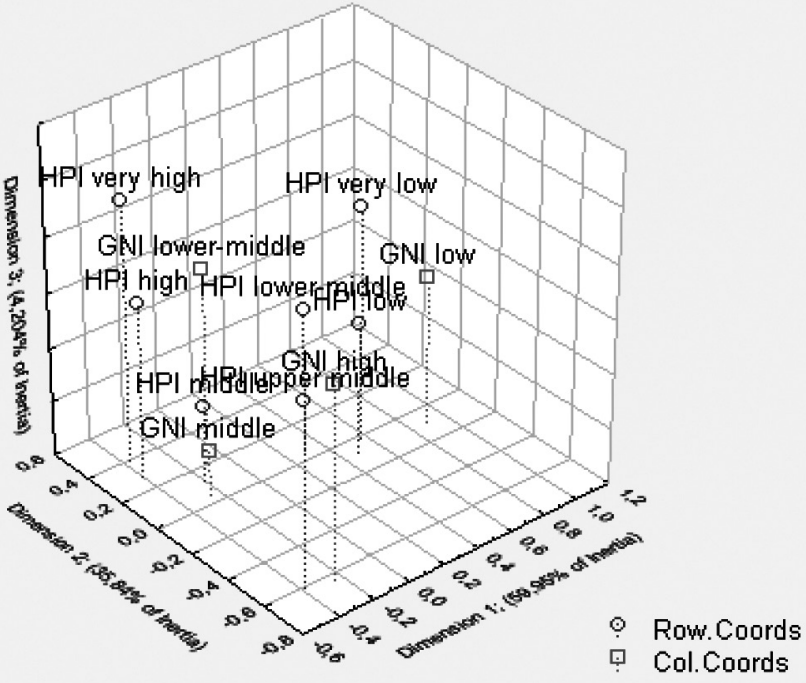

Fig. 7. 3-D graph of coordinates of rows and columns

Source: own study. 


\begin{tabular}{|c|c|c|c|c|c|}
\hline & \multicolumn{5}{|c|}{$\begin{array}{l}\text { Percentages of Row Totals (corespondent_HPI_GNI_all) } \\
\text { Input Table (Rows } \times \text { Columns): } 7 \times 4 \\
\text { Total Inertia }=24766 \text { Chi?=33,930 df=18 } \mathrm{p}=, 01288\end{array}$} \\
\hline & GN low & $\begin{array}{c}\text { GNI } \\
\text { lower-middle }\end{array}$ & GNI middle & GNI high & Total \\
\hline $\mathrm{HPI}$ very high & 0,00000 & 76,92308 & 15,38462 & 7,69231 & 100,0000 \\
\hline HPI high & 0,0 & 68,42105 & 21,05263 & 10,52632 & 100,0000 \\
\hline HPI upper middle & 4,54545 & 36,36364 & 18,18182 & 40,90909 & 100,0000 \\
\hline $\mathrm{HPI}$ middle & 8,33333 & 54,16667 & 25,00000 & 12,50000 & 100,0000 \\
\hline HPI lower-middle & 25,92593 & 48,14815 & 14,81481 & 11,11111 & 100,0000 \\
\hline HPI low & 33,33333 & 40,000000 & 13,33333 & 13,33333 & 100,0000 \\
\hline HPI very low & 35,29412 & 47,05882 & 5.88235 & 11,76471 & 100,00000 \\
\hline
\end{tabular}

Fig. 8. Table of relative frequencies by lines

Source: own study.

\begin{tabular}{|c|c|c|c|c|}
\hline & \multicolumn{4}{|c|}{$\begin{array}{l}\text { Percentages of Column Totals (corespondent_HPI } \\
\text { Input Table (Rows } \times \text { Columns): } 7 \times 4 \\
\text { Total Inertia= } 24766 \text { Chi?=33,930 df=18 } \mathrm{p}=, 01288\end{array}$} \\
\hline & GNI low & $\begin{array}{c}\text { GNI } \\
\text { lower-middle }\end{array}$ & GNI middle & GNI high \\
\hline HPI very high & 0,0000 & 14,0845 & 8,6957 & 4,5455 \\
\hline HPI high & 0,0000 & 18,3099 & 17,3913 & 9,0909 \\
\hline HPI upper middle & 4,7619 & 11,2676 & 17,3913 & 40,9091 \\
\hline HPI middle & 9,5238 & 18,3099 & 26,0870 & 13,6364 \\
\hline HPI lower-middle & 33,3333 & 18,3099 & 17,3913 & 13,6364 \\
\hline HPI low & 23,8095 & 8,4507 & 8,6957 & 9,0909 \\
\hline $\mathrm{HPI}$ very low & 28,5714 & 11,2676 & 4,3478 & 9,0909 \\
\hline
\end{tabular}

Fig. 9. Table of relative frequencies by columns

Source: own study.

The final goal of the correspondence analysis is the interpretation of vectors in the resulting space of inferior dimension. One way that can help in interpreting the results is to display the columns in the diagram.

We can assume that the first axis gives a gradation of the Happy Planet Index. So, a greater degree of similarity between countries with very low HPI and countries with lower-middle HPI can be explained by the presence in these groups of a large number of countries with a low level of Gross National Income (Figure 9).

Assessment of the quality of the solution. Special statistics are used to evaluate the quality of the solution obtained. All or most of the points should be correctly represented - the distances between them as a result of applying the correspondence analysis procedure are not distorted.

The results of calculating statistics on the available row and column coordinates for a two-dimensional solution are shown in Figures 10-11. 


\begin{tabular}{|l|l|l|l|l|l|l|l|l|l|}
\hline \multirow{8}{*}{$\begin{array}{l}\text { Row Coordinates and Contributions to Inertia (corespondent_HPI_GNI_all) } \\
\text { Input Table (Rows } x \text { Columns): } 7 \times 4\end{array}$} \\
Standardization: Row and column profiles
\end{tabular}

Fig. 10. Coordinates and input line in inertia

Source: own study.

\begin{tabular}{|c|c|c|c|c|c|c|c|c|c|c|}
\hline \multirow[b]{2}{*}{$\begin{array}{l}\text { Column } \\
\text { Name }\end{array}$} & \multicolumn{10}{|c|}{$\begin{array}{l}\text { Column Coordinates and Contributions to Inertia (corespondent_HPI_GNI_all) } \\
\text { Input Table (Rows } \times \text { Columns): } 7 \times 4 \\
\text { Standardization: Row and column profiles }\end{array}$} \\
\hline & \begin{tabular}{|l|} 
Column \\
Number
\end{tabular} & $\begin{array}{l}\text { Caordin. } \\
\text { Dim.1 }\end{array}$ & $\begin{array}{c}\text { Coordin. } \\
\text { Dim.2 }\end{array}$ & Mass & Quality & $\begin{array}{c}\begin{array}{c}\text { Relative } \\
\text { Inertia }\end{array} \\
\end{array}$ & $\begin{array}{l}\text { Inertia } \\
\text { Dim.1 }\end{array}$ & $\begin{array}{c}\text { Cosine? } \\
\text { Dim.1 }\end{array}$ & $\begin{array}{l}\text { Inertia } \\
\text { Dim.2 }\end{array}$ & $\begin{array}{c}\text { Cosine? } \\
\text { Dim.2 }\end{array}$ \\
\hline GNI low & 1 & 0,892549 & $-0,089130$ & 0,153285 & 0,999106 & 0,498424 & 0,822394 & 0,989241 & 0,013718 & 0,009865 \\
\hline GNN lower-middle & 2 & $-0,105089$ & 0,209985 & 0,518248 & 0,936599 & 0,123188 & 0,038545 & 0,187594 & 0,257434 & 0,749005 \\
\hline GNI middle & 3 & $-0,252739$ & 0,0390997 & 0,167883 & 0,582131 & 0,076162 & 0,072222 & 0,568526 & 0,002891 & 0,013605 \\
\hline GNI high & 4 & $-0,248603$ & $-0,633474$ & 0,160584 & 0,993515 & 0,302227 & 0,066839 & 0,132592 & 0,725957 & 0,860923 \\
\hline
\end{tabular}

Fig. 11. Coordinates and input columns in inertia

Source: own study.

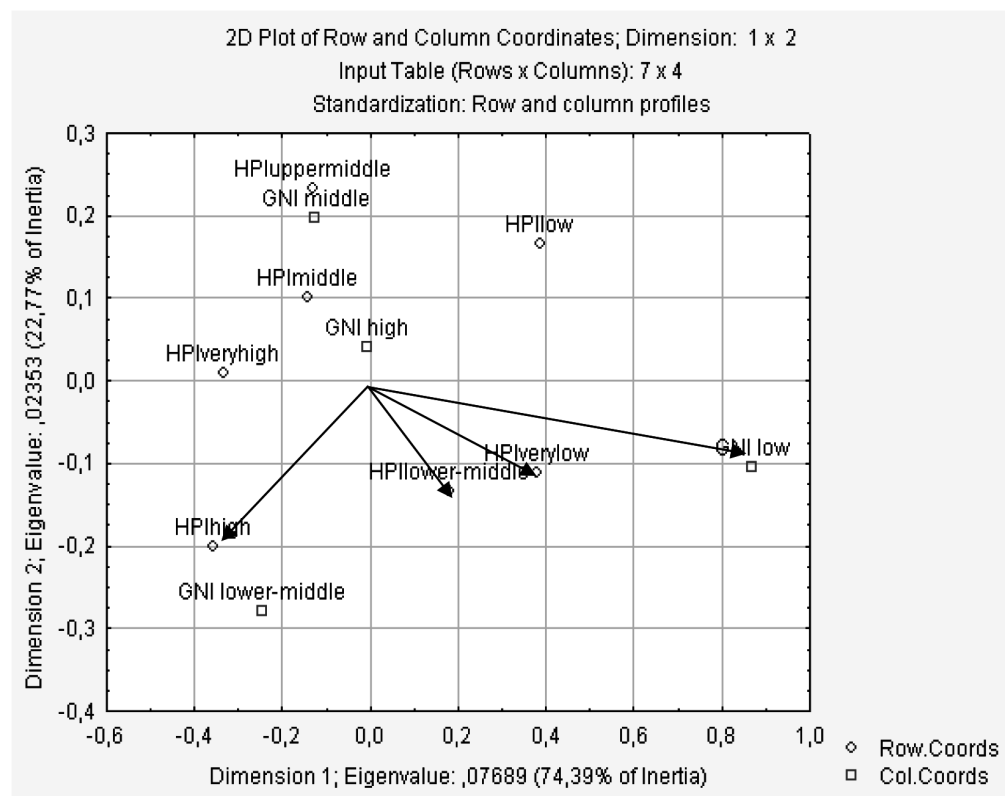

Fig. 12. Visual assessment of the relationship between points of different types

Source: own study. 
Quality is high for all groups of countries except countries with a middle Happy Planet Index, for which the quality is sufficient, so the selected number of dimensions represents all the rows and columns of the original data table.

Graphical analysis of the results of the relationship between the Happy Planet Index and Gross National Income (Figure 12) confirmed the presence of a direct link between the groups of countries with very low HPI and the low levels of Gross National Income, as well as among the countries with lower-middle HPI and countries with a low level of Gross National Income. Among countries with a high level of HPI and a high level of Gross National Income, there is an opposite relationship, which suggests that there is a level of income when the level of happiness does not increase with the growth in the amount of money.

\section{Final remarks}

The approaches to studying the problems of sustainable development have changed significantly in recent years. Today, we are talking not only about financial enrichment and the pace of economic growth but also about its direction. The issues of ensuring the competitiveness of countries, social cohesion, reducing poverty, reducing inequality, ensuring political freedoms and solving environmental problems have become important.

In the paper, the relationship between the Happy Planet Index, in which all the main dimensions of a happy life (life expectancy, perceived wellbeing, inequality of outcomes, ecological footprint), and one of the main measures of the income level of the population, Gross National Income per capita, has been investigated. The study has shown that income level is not the main criterion in assessing the level of happiness and the sustainable development of a country. Moreover, there is a critical feature when the level of satisfaction with life becomes lower with the same income growth.

Although sustainable development may seem a normative process, there is no consensus among scientists on the nature and speed of the necessary actions in this direction. In addition, there are disagreements about the different interests that may be violated. Many decisions needed to ensure sustainable development require a high level of global consensus, which can only be formed on the basis of rigorous scientific facts and knowledge. Therefore, statistical and mathematical methods become critical for obtaining facts.

\section{Bibliography}

Butlin J., 1987, Our common future. By the World Commission on Environment and Development, Journal of International Development, no. 1(2).

Countries in the world by population, 2018, Worldometers. Retrieved from http://www.worldometers. info. 
GNI per capita, Atlas method (current US\$) - Country Ranking, 2018, Index mundi. Retrieved from [income] https://www.indexmundi.com/facts/indicators/NY.GNP.PCAP.CD/rankings.

Hack P.A., 2018, New Generation of Data for Human Development. Retrieved from http://hdr.undp. org/sites/default/files/hackl_final_02.pdf.

Human Development Report, 1990, United Nations Development Programme, Oxford University Press, New York. Retrieved from

http://hdr.undp.org/sites/default/files/reports/219/hdr_1990_en_complete_nostats.pdf.

Kovalchuk O., 2017, Mathematical Modeling of Sustainable Development. Monograph, TNEU, Ternopil.

Oprean M., Vanu A., Bucur A., 2009, Sustainable development modeling, Manag. Sustain. Dev., 1, pp. 10-18.

Permanyer I., Smits J., The Subnational (2018). Human Development Index: Moving beyond country-level averages. Retrieved from http://hdr.undp.org/en/content/subnational-human-developmentindex-moving-beyond-country-level-averages.

Sen A., 1999, Development as Freedom, Oxford University Press, Oxford.

Stewart F., Samman E., 2018, Advancing Human Development: Theory and Practice. Human Development Reports Office. Retrieved from.http://hdr.undp.org/en/content/advancing-human-development-theory-and-practice.

The Happy Planet Index, 2016, retrieved from www.happyplanetindex.org.

Todorov V., Marinova D., 2010, Modelling sustainability, Mathematics and Computers in Simulation, 81(7), pp. 1397-1408.

\section{ANALIZA KORESPONDENCJI JAKO NARZĘDZIE DO MODELOWANIA KOMPUTEROWEGO ZRÓWNOWAŻONEGO ROZWOJU}

Streszczenie: Wiele problemów współczesnego świata jest wynikiem niestałego rozwoju. Globalne zmiany klimatu, wyczerpywanie się zasobów, śmieci kosmiczne, ubóstwo, nierówności społeczne oraz zagrożenia dla bezpieczeństwa globalnego są zasadniczymi, lecz nie jedynymi wyzwaniami dla współczesnego człowieczeństwa. Podstawową kwestią w badaniu problemów zrównoważonego rozwoju krajów jest opracowanie strategii umożliwiających uniknięcie społecznej i ekologicznej katasrtofy. W artykule wykorzystano analizę korespondencji dla ujawnienia powiązań pomiędzy Happy Planet Index (będącym agregowanym wskaźnikiem osiągnięć w najważniejszych aspektach rozwoju ludzkości: trwanie i jakość życia, jednolitość w dystrybucji osiągnięć, dostęp do wiedzy, ochrona środowiska) a Gross National Income (jednym z kluczowych mierników poziomu bogactwa ludności). Przeprowadzona analiza pozwoliła stwierdzić, że poziom dochodów ludności nie jest podstawowym czynnikiem przy ocenianiu poziomu zrównoważonego rozwoju poszczególnych państw. Otrzymane wyniki mogą przynieść bardzo ważne informacje dla instytucji społecznych oraz polityków.

Słowa kluczowe: zrównoważony rozwój, analiza korespondencji, modelowanie komputerowe, Happy Planet Index, dochód narodowy brutto. 